\title{
Development of sparse Bayesian multinomial generalized linear model for multi-class prediction
}

\author{
Behrouz Madahian', Lih Y Deng ${ }^{1}$, Ramin Homayouni ${ }^{2,3^{*}}$ \\ From UT-KBRIN Bioinformatics Summit 2014 \\ Cadiz, KY, USA. 11-13 April 2014
}

\section{Background}

Gene expression profiling has been used for many years to classify samples and to gain insights into the molecular mechanisms of phenotypes and diseases. A major challenge in expression analysis is caused by the large number of variables assessed compared to relatively small sample sizes. In addition, identification of markers that accurately predict multiple classes of samples, such as those involved in the progression of cancer or other diseases, remains difficult.

\section{Materials and methods}

In this study, we developed a multinomial Probit Bayesian model which utilized the double exponential prior to induce shrinkage and reduce the number of covariates in the model [1,2]. A fully Bayesian hierarchical model was developed in order to facilitate Gibbs sampling which takes into account the progressive nature of the response variable. Gibbs sampling was performed in $\mathrm{R}$ for $100 \mathrm{k}$ iterations and the first $20 \mathrm{k}$ were discarded as burn-in. The method was applied to a published dataset on prostate cancer progression downloaded from Gene Expression Omnibus at NCBI (GSE6099) [3]. The data set contained 99 prostate cancer cell types in four different progressive stages. The dataset was randomly divided into training $(\mathrm{N}=50)$ and test $(\mathrm{N}=49)$ groups such that each group contained an equal number of each cell type. Before applying our model, for each gene we performed ordinal logistic regression. Genes were ranked based on the p-value of association. Using a cutoff value of 0.05 after Benjamini and Hochberg FDR correction resulted in a final set of 398 genes.

\footnotetext{
* Correspondence: rhomayon@memphis.edu

${ }^{2}$ Bioinformatics Program, University of Memphis, Memphis, TN, 38152, USA Full list of author information is available at the end of the article
}

\section{Results}

Figure 1 shows the posterior mean of parameters associated with each gene. Using the top ten genes obtained from our model, we were able to achieve $86 \%$ classification accuracy in the training group and $82 \%$ accuracy in the test group. To test the robustness of the model, we switched the training and test groups and evaluated the classification accuracy. We obtained $88 \%$ classification accuracy on the new training group and $86 \%$ accuracy on the new test group. The classification accuracy by tumor type is shown in Table 1. Taken together, these results suggest that the Bayesian Multinomial Probit model applied to cancer progression data allows for reasonable subclass prediction.

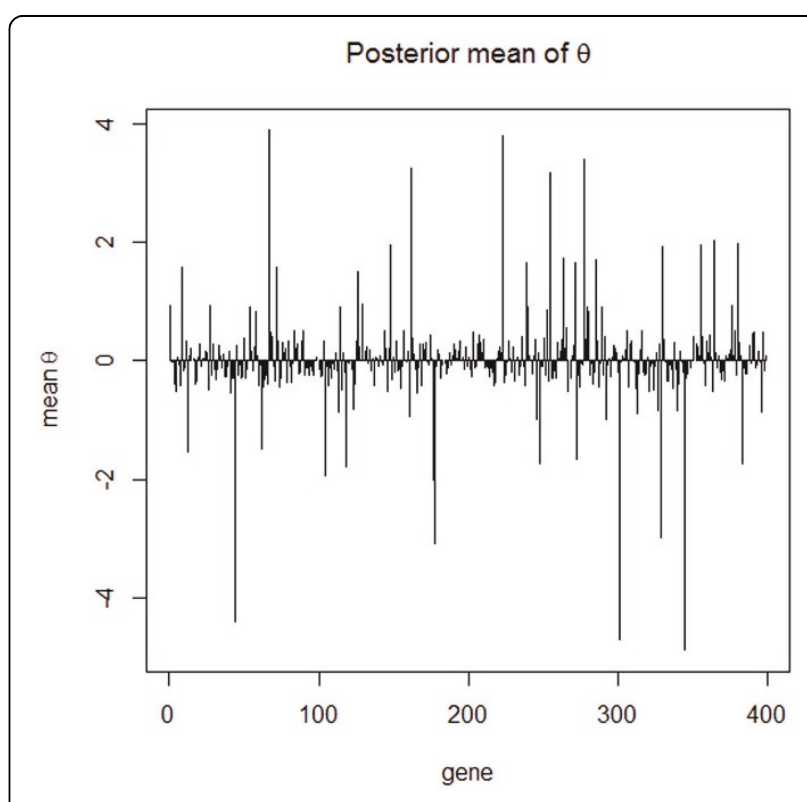

Figure 1 Posterior mean of $\theta$ s associated with gene1 to gene 398. 
Table 1 Classification accuracy of prostate cancer subtypes in the train and test groups.

\begin{tabular}{ccccc}
\hline Sample type & Train group & Test group & Train group Switched & Test group switched \\
\hline Benign & 100 & 94 & 100 & 100 \\
PIN & 29 & 33 & 50 & 71 \\
PCA & 86 & 86 & 100 & 100 \\
MET & 100 & 100 & 70 & 50 \\
\hline
\end{tabular}

\section{Conclusion}

Our future plan is to perform resampling on the selection of training and test groups in order to obtain more robust results and to compare the performance of the model to other popular classifiers such as Support Vector Machine and Random Forest.

\section{Acknowledgments}

This work was supported by the University of Memphis Center for Translational Informatics and the Assisi Foundation of Memphis.

\section{Authors' details}

'Department of Mathematical Sciences, University of Memphis, Memphis, TN, 38152, USA. 'Bioinformatics Program, University of Memphis, Memphis, TN,

38152, USA. ${ }^{3}$ Department of Biology, University of Memphis, Memphis, TN

38152, USA

Published: 29 September 2014

\section{References}

1. Park T, Casella G: The Bayesian lasso. J Am Stat Assoc 2008, 103:681-686.

2. Albert J, Chib S: Bayesian analysis of binary and polychotomous response data. J Am Stat Assoc 1993, 88:669-679.

3. Tomlins SA, Mehra R, Rhodes DR, Cao X, Wang L, Dhanasekaran SM, Kalyana-Sundaram S, Wei JT, Rubin MA, Pienta KJ, Shah RB, Chinnaiyan AM: Integrative molecular concept modeling of prostate cancer progression. Nat Genet 2007, 39(1):41-51.

doi:10.1186/1471-2105-15-S10-P14

Cite this article as: Madahian et al:: Development of sparse Bayesian multinomial generalized linear model for multi-class prediction. $B M C$ Bioinformatics 2014 15(Suppl 10):P14.

Submit your next manuscript to BioMed Central and take full advantage of:

- Convenient online submission

- Thorough peer review

- No space constraints or color figure charges

- Immediate publication on acceptance

- Inclusion in PubMed, CAS, Scopus and Google Scholar

- Research which is freely available for redistribution

Submit your manuscript at www.biomedcentral.com/submit
C Biomed Central 